Research Article

\title{
Long-term effect of crops and fertilization on soil eco-chemical state
}

\author{
Jerzy Jonczak \\ Warsaw University of Life Sciences, Warsaw, Poland
}

Article Details: Received: 2020-12-29｜Ａccepted: 2021-03-08｜Ａvailable online: 2021-05-31

(c) (i) $(-)$ Licensed under a Creative Commons Attribution 4.0 International License

\begin{abstract}
The study on long-term effects of various crops and fertilization practices on soil eco-chemical state was performed in the complex of Planosols at the Warsaw University of Life Sciences - SGGW experimental station in Skierniewice. The study covered three experiments - Ex-1 (established in 1923; no organic fertilization, cereals as a crop), Ex-2 (established in 1992; farmyard manure application every 4 years, cereals as a crop) and Ex-3 (established in 1975; no organic fertilization, blueberries as a crop). Additionally, each experiment covered three mineral fertilization options, including no fertilization, NPK and CaNPK. Soil samples were taken from A-horizons in 2017 and analysed using standard procedures. The results demonstrate considerable influence of crops and fertilization practices on soil eco-chemical state. Both mineral and organic fertilizers positively affected sorptive capacity as compared to control and modified ionic composition of soil sorption complex. Lower exchangeable acidity and higher sum of exchangeable basis and base saturation were noted in fertilized soils and cereals as a crop as compared to controls. Under blueberries there was observed strong acidification of the soil, in particular in combination with NPK fertilizers, as evidenced by the highest exchangeable acidity, hydrolytic acidity, and the lowest base saturation. Liming partially neutralized acidifying effect of blueberries. Fertilization and crops also strongly influenced buffering capacity of the soils. Extremely low ability to neutralize acidic ions was noted in unfertilized soils, whereas the highest at plots fertilized with $\mathrm{Ca}$. The highest ability to neutralize alkaline ions was typical for NPK fertilized soils under blueberries.
\end{abstract}

Keywords: soil pH, soil sorption, buffering capacity, fertilization, soil quality

\section{Introduction}

Tillage is one of most widespread form of human impact on soil cover being sometimes highly destructive. However, it is a complicated issue that covers various aspects of crop rotation, cultivation technologies and fertilization and their influence on soil chemistry, physical properties, soil organic matter quality and quantity, and many others. Although above-mentioned issues have been frequently studied, there is still not sufficient knowledge in some fields. First of all, there is relatively little data from long-term, fully controlled field experiments. Most of publications are based on single sampling of the soils under various uses (crops/ fertilization/other factors) or short-term observations with no sufficient reconstruction of land-use history, crop rotation, and fertilization. Therefore, the obtained data cannot be precisely interpreted, and final conclusions are not certain. Considering increasing intensity of agricultural production due to growing human population and limited resistance of the soils to external factors, detailed studies on tillage (in general) impact on soil cover are highly recommended.

The purpose of this study was to evaluate long-term effects of two crops (cereals and blueberries) and several fertilization practices (various combinations of farmyard manure, NPK, and CaNPK fertilizers) on chosen indicators of soil eco-chemical state, including $\mathrm{pH}$, sorptive properties and buffering capacity. The studied soil properties are of key importance for nutrients management in arable soils and may influence environmental quality of agroecosystems.

\section{Material and methods}

The studies were performed at the Warsaw University of Life Sciences - SGGW experimental station in Skierniewice $\left(51^{\circ} 57^{\prime} 54.3^{\prime \prime} \mathrm{N}, 20^{\circ} 9^{\prime} 31.8^{\prime \prime} \mathrm{E}\right)$. Average annual temperatures for this region are around $8{ }^{\circ} \mathrm{C}$, whereas

\footnotetext{
*Corresponding Author: Jerzy Jonczak, Warsaw University of Life Sciences-SGGW, Department of Soil Science, Nowoursynowska Str. 159, 02-787 Warsaw, Poland, $\mathbf{m}$ +48 $022 \quad 59326$ 17; e-mail: jerzy_jonczak@sggw.edu.pl
} 
sum of precipitation varies around $530 \mathrm{~mm}$. The station is located in a flat post-glacial landscape and Planosols developed form sandy substrates over loams are typical soils. Beginning from the year 1923, in the station there are conducted long-term experiments on the effects of various crops and fertilization practices on soil properties and plant yielding. This study was based on three major experiments and several fertilization options, according to Fig. 1. Experiment 1 (Ex-1, established in 1923) covers various options of mineral fertilization without organic fertilization and cereals as a crop. Experiment 2 (Ex-2, established in 1992) covers various options of mineral fertilization and farmyard manure application at rate of 25 t.ha $^{-1}$ every 4 years and cereals as a crop. The last experiment (Ex-3, established in 1975) covers various options of mineral fertilization without organic fertilization and blueberry as a crop. The following options of mineral fertilization were chosen for this study: control (no mineral fertilization), NPK, and CaNPK. In all experiments nitrogen was applied as ammonium sulfate (30 kg.ha-1 of
$\mathrm{N}$ from 1921 to 1976 and $90 \mathrm{~kg} \cdot \mathrm{ha}^{-1}$ of $\mathrm{N}$ from 1976), phosphorus as superphosphate (30 kg.ha-1 of $\mathrm{P}_{2} \mathrm{O}_{5}$ from 1921 to 1976 and $26 \mathrm{~kg} \cdot \mathrm{ha}^{-1}$ of $\mathrm{P}_{2} \mathrm{O}_{5}$ from 1976) and potassium as potassium chloride $\left(30 \mathrm{~kg} \cdot \mathrm{ha}^{-1}\right.$ of $\mathrm{K}_{2} \mathrm{O}$ from 1921 to 1976 and 91 kg.ha-1 of $\mathrm{K}_{2} \mathrm{O}$ from 1975). Calcium was applied every 4 years as 1.6 t.ha $^{-1}$ of $\mathrm{CaO}$. All fertilization options covered three replications. The size of a single plot was $4 \times 9 \mathrm{~m}\left(36 \mathrm{~m}^{2}\right)$, and spacing between the plots was $2 \mathrm{~m}$.

The soils were sampled in August 2017. Three cores from A-horizons were taken from each plot and mixed into one average sample. The samples were air-dried and sieved though a $2.0 \mathrm{~mm}$ sieve. Earth fraction $(<2.0 \mathrm{~mm})$ was used for the further analysis. Bulk samples were taken from central parts of A-horizon using the $100 \mathrm{~cm}^{3}$ steel rings. The following laboratory analyses were done:

- Bulk density and total porosity using the gravimetric method (Bednarek et al., 2004).

- Particle-size distribution by mixed pipette and sieve methods. The Polish Soil Science Society classification (PTG, 2009) was

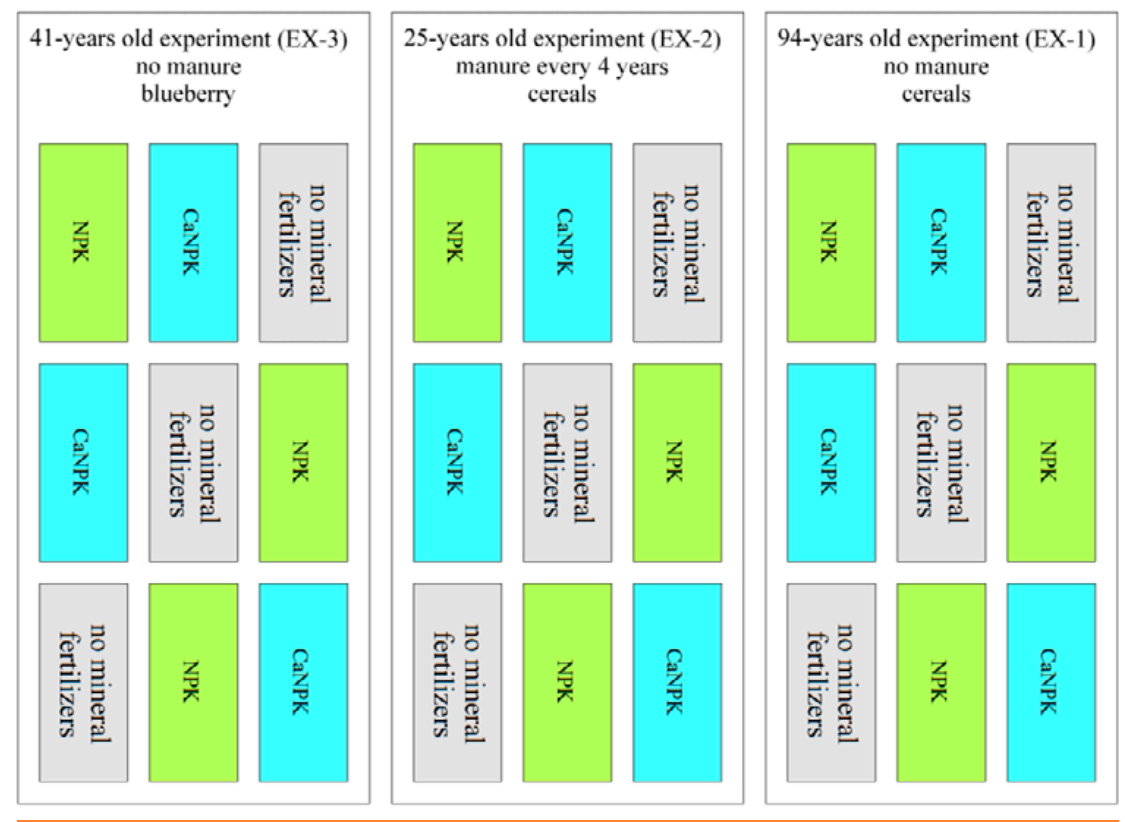

Figure 1 Design of the experiment applied to determine textural fractions and groups.

- $\mathrm{pH}$ by the potentiometric method in a suspension with water and $1 \mathrm{~mol}^{\mathrm{dm}} \mathrm{m}^{-3}$ solution of KCl (Bednarek et al., 2004).

- The content of total organic carbon (TOC) and total nitrogen (N) by dry combustion (Vario MacroCube, Elementar).

- The contents of basic cations ( $\mathrm{Ca}^{2+}$, $\mathrm{Mg}^{2+}, \mathrm{Na}^{+}$and $\mathrm{K}^{+}$) by inductivelycoupled plasma atomic emission spectrometry (ICP-OES, Avio 200, Perkin Elmer) after samples extraction in $1 \mathrm{~mol} . \mathrm{dm}^{-3}, \mathrm{pH}=7.0$ solution of ammonium acetate.

- Exchange acidity $\left(H_{w}\right)$ by the Sokolov method (Bednarek et al., 2004).

- Hydrolytic acidity $\left(H_{h}\right)$ by the Kappen method (Bednarek et al., 2004).

- Buffering properties according to the Arrhenius procedure (Bednarek et al., 2004).

Moreover, the following parameters were calculated based on the results obtained: sum of exchangeable basis (TEB) as a sum of exchangeable $\mathrm{Ca}^{2+}$, $\mathrm{Mg}^{2+}, \mathrm{Na}^{+}$and $\mathrm{K}^{+}$; cation exchange capacity (CEC) as TEB $+H_{w}$; basic saturation of soil sorption complex (BS) as $(T E B \times 100) / C E C$. Statistical analysis included measures of central tendencies and dispersal, Dunn's test, correlations, and cluster analysis.

\section{Results and discussion}

\subsection{Basic characteristics of the soils}

Humic horizons of the studied Planosols were characterised by loamy sand texture at every plot, and contained $72.9-81.5 \%$ of sand (2.0-0.05 mm), $13.8-19.7 \%$ of silt $(0.05-0.002 \mathrm{~mm})$ and $4.0-7.7 \%$ of clay $(<0.002 \mathrm{~mm})$ fractions. Bulk density ranged from 1.45 to $1.66 \mathrm{~g} . \mathrm{cm}^{-3}$, whereas total porosity from 35.6 to $44.6 \%$ during the study period (Table 1). The soils contained 
Table 1 Basic physical characteristics of the soils

\begin{tabular}{|c|c|c|c|c|c|c|c|}
\hline $\begin{array}{l}\text { Experiment } \\
\text { options }\end{array}$ & Replicates & $\begin{array}{l}\text { Textural } \\
\text { group }\end{array}$ & $\begin{array}{c}\text { Bulk density } \\
\left(\mathbf{g} \cdot \mathrm{cm}^{-3}\right)\end{array}$ & $\begin{array}{c}\text { Total } \\
\text { porosity (\%) }\end{array}$ & $\begin{array}{c}\text { TOC } \\
\left(\mathbf{g} \cdot \mathbf{k g}^{-1}\right)\end{array}$ & $\begin{array}{c}\mathbf{N} \\
\left(\mathbf{g} \cdot \mathbf{k g}^{-1}\right)\end{array}$ & TOC/N \\
\hline \multirow{3}{*}{ Ex-1/Cont. } & 1 & $\mathrm{LS}^{*}$ & 1.60 & 38.9 & 4.73 & 0.430 & 11.0 \\
\hline & 2 & LS & 1.52 & 42.2 & 4.36 & 0.370 & 11.8 \\
\hline & 3 & LS & 1.59 & 39.8 & 3.79 & 0.378 & 10.0 \\
\hline \multirow{3}{*}{ Ex-1/NPK } & 1 & LS & 1.66 & 36.5 & 5.80 & 0.544 & 10.7 \\
\hline & 2 & LS & 1.58 & 40.9 & 5.42 & 0.466 & 11.6 \\
\hline & 3 & LS & 1.59 & 39.3 & 5.50 & 0.476 & 11.6 \\
\hline \multirow{3}{*}{ Ex-1/CaNPK } & 1 & LS & 1.66 & 36.9 & 6.58 & 0.604 & 10.9 \\
\hline & 2 & LS & 1.61 & 40.1 & 5.04 & 0.437 & 11.5 \\
\hline & 3 & LS & 1.56 & 43.2 & 4.88 & 0.392 & 12.5 \\
\hline \multirow{3}{*}{ Ex-2/Cont. } & 1 & LS & 1.59 & 38.2 & 5.87 & 0.543 & 10.8 \\
\hline & 2 & LS & 1.50 & 41.8 & 5.04 & 0.520 & 9.7 \\
\hline & 3 & LS & 1.58 & 39.1 & 5.70 & 0.538 & 10.6 \\
\hline \multirow{3}{*}{ Ex-2/NPK } & 1 & LS & 1.64 & 37.1 & 7.11 & 0.671 & 10.6 \\
\hline & 2 & LS & 1.47 & 42.2 & 8.39 & 0.833 & 10.1 \\
\hline & 3 & LS & 1.48 & 42.7 & 6.98 & 0.603 & 11.6 \\
\hline \multirow{3}{*}{ Ex-2/CaNPK } & 1 & LS & 1.51 & 42.3 & 8.48 & 0.782 & 10.8 \\
\hline & 2 & LS & 1.50 & 44.6 & 8.41 & 0.759 & 11.1 \\
\hline & 3 & LS & 1.55 & 40.5 & 6.52 & 0.563 & 11.6 \\
\hline \multirow{3}{*}{ Ex-3/Cont. } & 1 & LS & 1.53 & 41.3 & 6.23 & 0.462 & 13.5 \\
\hline & 2 & LS & 1.60 & 38.8 & 7.61 & 0.503 & 15.1 \\
\hline & 3 & LS & 1.59 & 38.2 & 4.68 & 0.372 & 12.6 \\
\hline \multirow{3}{*}{ Ex-3/NPK } & 1 & LS & 1.45 & 43.1 & 11.23 & 0.913 & 12.3 \\
\hline & 2 & LS & 1.49 & 42.5 & 7.29 & 0.562 & 13.0 \\
\hline & 3 & LS & 1.52 & 40.4 & 11.79 & 0.783 & 15.1 \\
\hline \multirow{3}{*}{ Ex-3/CaNPK } & 1 & LS & 1.65 & 35.6 & 7.82 & 0.698 & 11.2 \\
\hline & 2 & LS & 1.56 & 40.8 & 7.64 & 0.689 & 11.1 \\
\hline & 3 & LS & 1.59 & 39.2 & 7.84 & 0.591 & 13.3 \\
\hline
\end{tabular}

* LS - loamy sand

3.79-11.79 g. kg ${ }^{-1}$ of TOC and 0.37-0.91 g. $\mathrm{kg}^{-1}$ of N. Both TOC and $\mathrm{N}$ contents considerably varied between plots. TOC/N ratio ranged from $9.7: 1$ to $15.1: 1$.

\subsection{Soil pH}

Soil pH is an important factor influencing forms, mobility, bioavailability, and toxicity of chemical elements and various compounds. Therefore, it is a good indicator of living conditions of soil biota and biochemical processes (Kowalkowski, 2002; Błońska \& Januszek, 2010). It is also one of key factors influencing crop production and quality (e.g. Limon-Ortega \& Martinez-Cruz, 2014). Knowledge about $\mathrm{pH}$ and its feedbacks with other soil parameters is essential for the development of efficient nutrient management systems. Tillage and fertilization effects on soil $\mathrm{pH}$ have been frequently studied. The results of this study show importance of both crops and fertilization for this soil characteristics. Mean soil $\mathrm{pH}-\mathrm{H}_{2} \mathrm{O}$ varied from 5.03 to 6.53 , whereas $\mathrm{pH}-\mathrm{KCl}$ from 3.13 to 6.14 (Fig. 2). The lowest values were noted at plots Ex-3/NPK and Ex-3/ CaNPK followed by slightly higher at Ex-1/NPK and Ex-1/ Cont. The lowest pH at Ex-3/NPK and Ex-3/CaNPK plots can be explained by mixed effect of blueberries and $\mathrm{NH}_{4}^{+}$ application as fertilizer. Ammonium form of nitrogen is preferred by blueberries, however, their uptake by roots is associated with secretion of $\mathrm{H}^{+}$. Low $\mathrm{pH}$ at Ex-1/Cont. and Ex-1/NPK plots is probably an effect of leaching of basic cations and/or their removal with the crop. The process 
of SOM decomposition as a source of $\mathrm{H}^{+}$(e.g. Hulugalle \& Weaver, 2005) can also have some effect, however, the role of this factor is probably low and difficult for precise estimation. The highest $\mathrm{pH}$ noted at plots Ex-2/Cont., Ex-2/ CaNPK and Ex-1/CaNPK confirm importance of manure and Ca fertilizers as agents neutralizing soil acidity.

\subsection{Sorptive properties}

Soil sorption capacity is a measure of soil solid phase potential to absorb ionic substances. Clay minerals and soil organic matter (SOM) play a key role in this area (Thompson et al., 1989; Okołowicz, 1996; Jaworska et al., 2008). Therefore, effects of various external factors on this property should be considered mainly from the perspective of changes in clay mineralogy and SOM. Crop rotation and fertilization effects on CEC were subjects of numerous studies (e.g. Rojas et al., 2013; Šimanský \& Polláková, 2014). CEC in this study ranged from 3.06 to $6.76 \mathrm{cmol} . \mathrm{kg}^{-1}$. The observed values are typical for loamy sand and sandy loam, poor-moderately abundant in SOM soils (Raczuk, 2011). The lowest mean value of CEC was noticed at Ex-1/Cont. and Ex-1/NPK plots, whereas the highest at plots fertilized with calcium, in particular in combination with farmyard manure (Ex-2/CaNPK) (Fig. 3). Previous studies of Šimanský et al. (2019) showed that soil of the studied plots fertilized with farmyard manure is characterized by better quality of SOM as evidenced by higher content of humic acids and lower of fulvic acids. The observed differences between experimental options in terms of CEC were statistically significant in many cases. There was not observed a significant correlation between CEC vs TOC content and positive correlation with clay content $(r=0.618)$. The lack of positive correlation with TOC content can be explained by heterogeneity of SOM quality as affected by various tillage practices. Importance of SOM quality as a factor

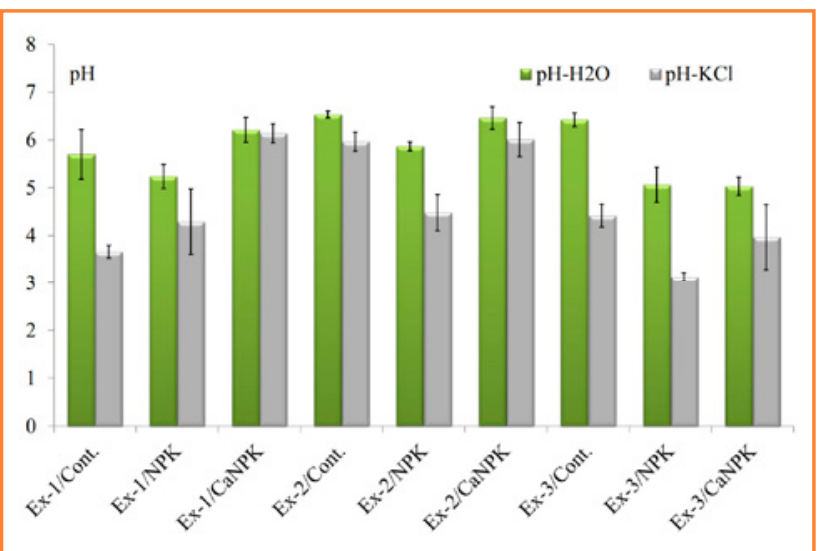

Figure 2 Soil $\mathrm{pH}$ under various crops and fertilization practices

mean values $\pm S D, n=3$

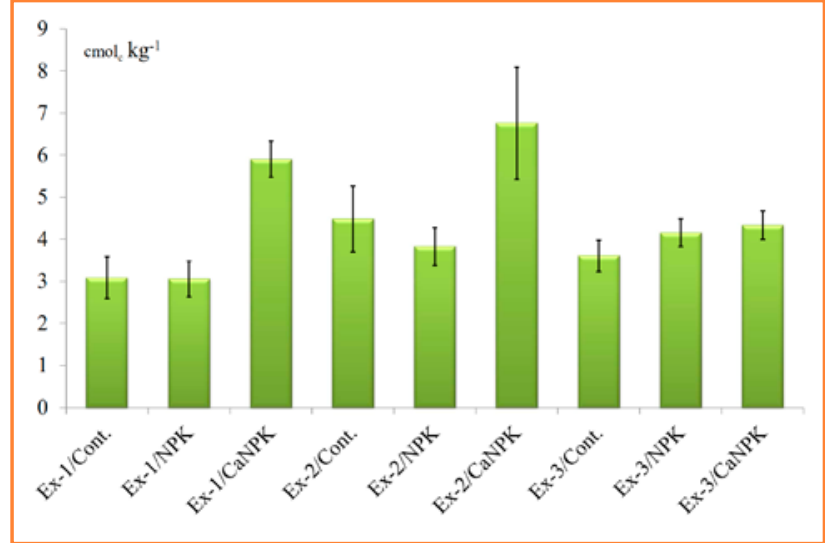

Figure 3 Cation exchange capacity under various crops and fertilization practices mean values $\pm S D, n=3$

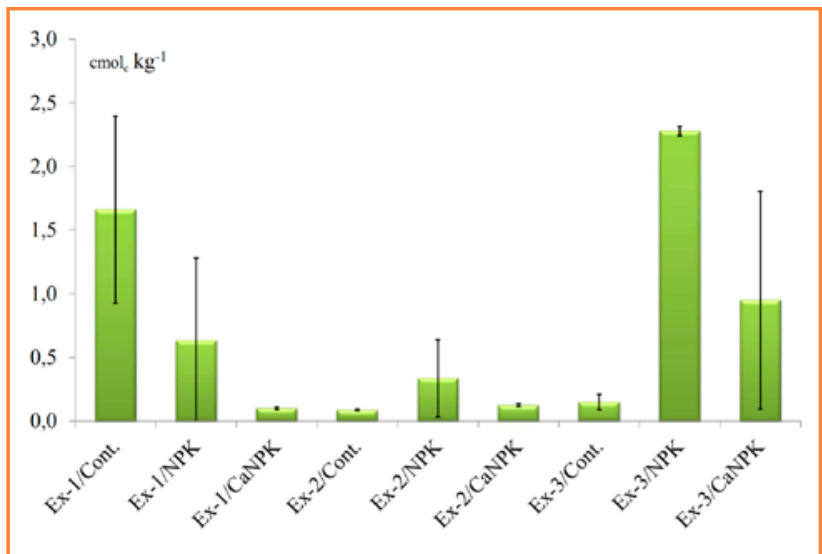

Figure 4 Exchangeable acidity in the soils under various crops and fertilization practices mean values $\pm \mathrm{SD}, n=3$

influencing sorption of ionic substances by the soils was confirmed by the results of many studies (e.g. Vang \& Huang, 2001; Kang et al., 2009).

Exchange acidity strongly varied among the studied plots - from 0.09 to $2.28 \mathrm{cmol}_{\mathrm{c}} \mathrm{kg}^{-1}$ (Fig. 4). It was the lowest at plots fertilized with $\mathrm{Ca}$ in experiments 1 and 2 and controls in experiment 2 and 3. The highest $H_{w}$ was noted for Ex-3/NPK and Ex-1/Cont. The observed tendencies confirm acidifying effect of blueberries and neutralizing effects of lime and manure in relation to acidic ions.

Hydrolytic acidity is the content of exchangeable acidic ions and their easily hydrolysable forms. It ranged from 1.21 to $6.07 \mathrm{cmol}_{\mathrm{c}} \cdot \mathrm{kg}^{-1}$, showing lower variability as compared to $H_{w}$. However, tendencies were also clear. The lowest values were generally observed at plots fertilized with $\mathrm{Ca}$ and/or farmyard manure, whereas the highest at Ex-3/NPK plots (Fig. 5). Positive correlation with TOC content $(r=0.592)$ confirm key role of SOM as a source of acidity. 


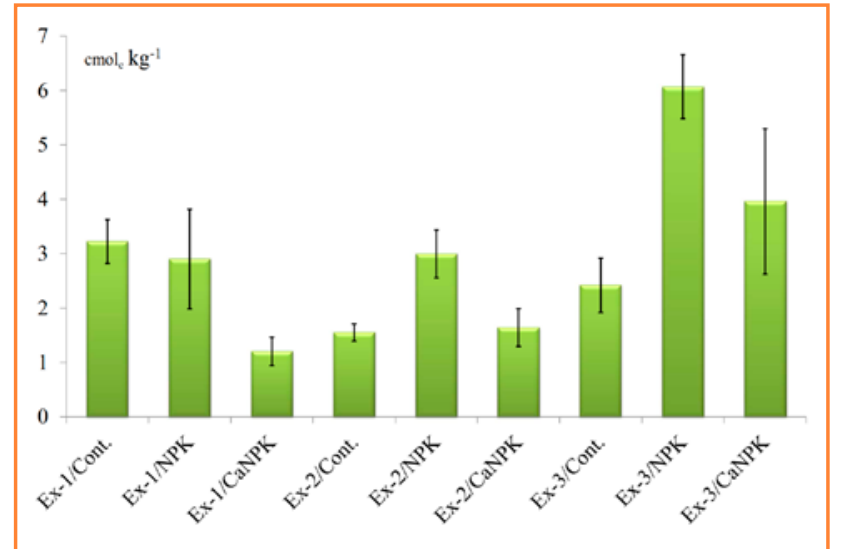

Figure 5

Hydrolytic acidity in the soils under various crops and fertilization practices mean values $\pm \mathrm{SD}, n=3$

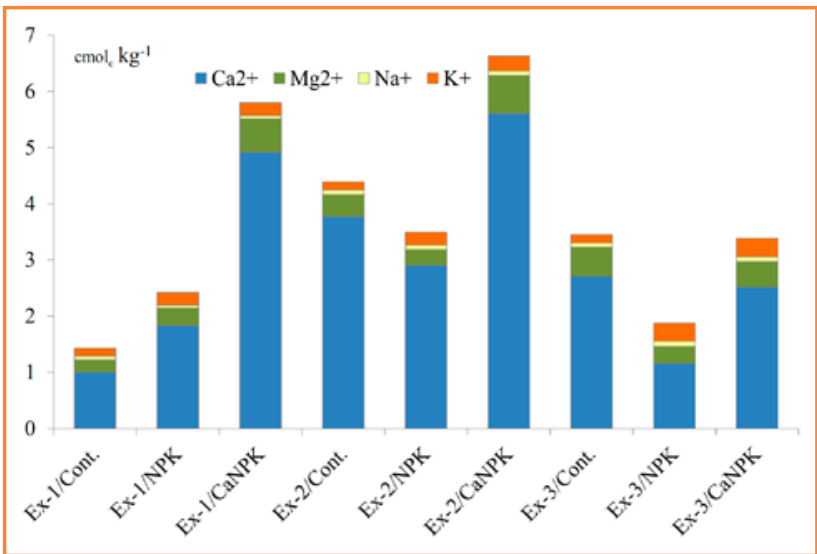

Figure 6
Average contents of basic cations in the soils under various crops and fertilization practices
Basic cations occurred at amounts from 1.43 to 6.63 $\mathrm{cmol}_{\mathrm{c}} \cdot \mathrm{kg}^{-1}$. Their lowest contents were noted at Ex-1/ Cont. plots followed by Ex-3/NPK. Most abundant were the plots fertilized with Ca in experiments 1 and 2 (Fig. 6). Generally, higher contents of exchangeable basis were recorded at plots with organic fertilization as compared to other plots. It highlights its important role as a source of basic cations. Calcium predominated among exchangeable basis in the studied soils, irrespective of crop and fertilization practices. It constituted $62.0-86.0 \%$ of basis on average. Exchangeable $\mathrm{Mg}$ constituted 7.9-15.8\%, K 3.3-17.1\% and $\mathrm{Na} 1.0-5.3 \%$ of basis (Fig. 7). The observed composition of soil sorption complex is typical for most soils of Poland (e.g. Orzechowski et al., 2005; Bartmiński \& Klimowicz, 2008). Basis constituted $45.2-98.3 \%$ of exchangeable cations on average. The lowest BS was observed at Ex-1/Cont. and Ex-3/NPK plots, whereas the highest at plots of experiment 2, in general.

The ability to neutralize acidic and alkaline ionic substances (buffering properties) is controlled by

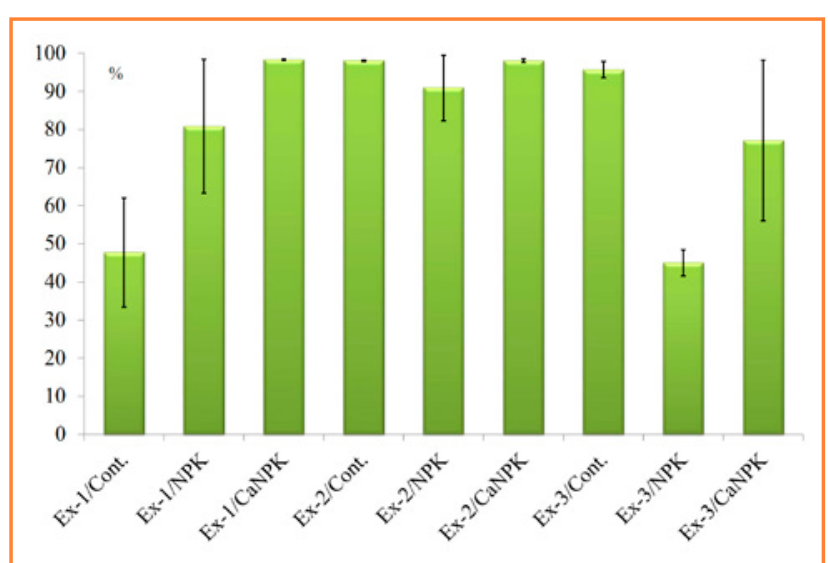

Figure $7 \quad$ Base saturation in the soils under various crops and fertilization practices mean values $\pm \mathrm{SD}, n=3$

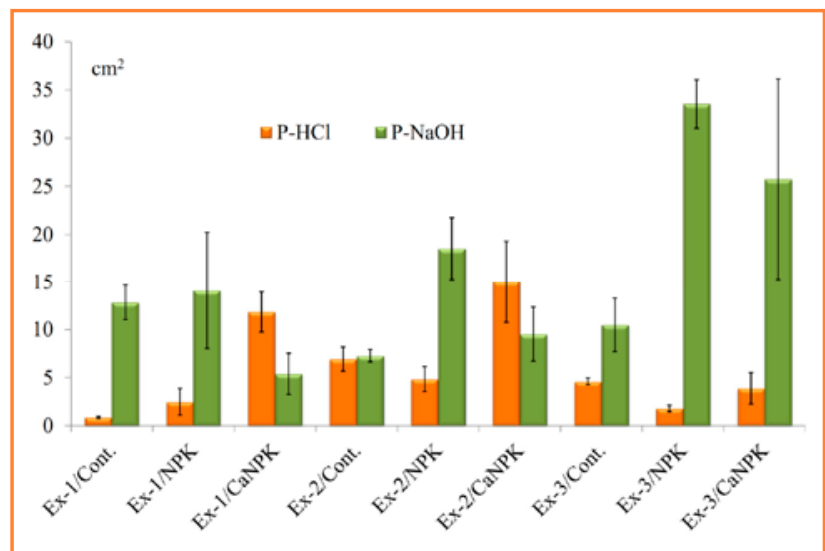

Figure 8 Buffering capacity $(\mathrm{PHCl}$ and $\mathrm{PNaOH})$ in the soils under various crops and fertilization practices mean values $\pm S D, n=3$

a complex of soil physical, physicochemical and chemical properties. $\mathrm{CaCO}_{3}$, clay minerals and SOM are the most important constituents in this area (Kowalkowski, 2002; Malczyk et al., 2008; Walenczak et al., 2009). Effects of some external factors on buffering capacity of the soils, including tillage and fertilization, are still poorly explored. Influence of some factors can be clearly explained; however, some have indirect effects. In the studied soils, buffering capacity of acids ranged from 0.86 to $15.03 \mathrm{~cm}^{2}$, whereas alkali from 5.40 to $33.54 \mathrm{~cm}^{2}$ (Fig. 8). The observed values are typical, considering characteristics of the soils (Raczuk, 2011). The lowest ability to neutralize acidic ions was noted at Ex-1/Cont. plots that were characterized by the lowest sorption capacity and content of basic cations. Only slightly higher values were observed for Ex-1/NPK and Ex-3/NPK experimental options. This observation demonstrates little relevance of NPK fertilization (in a form and doses like in the present study) as a factor increasing soil ability to neutralize acidic ions. The observation can be partially confirmed by Lieb et al. (2011), who 


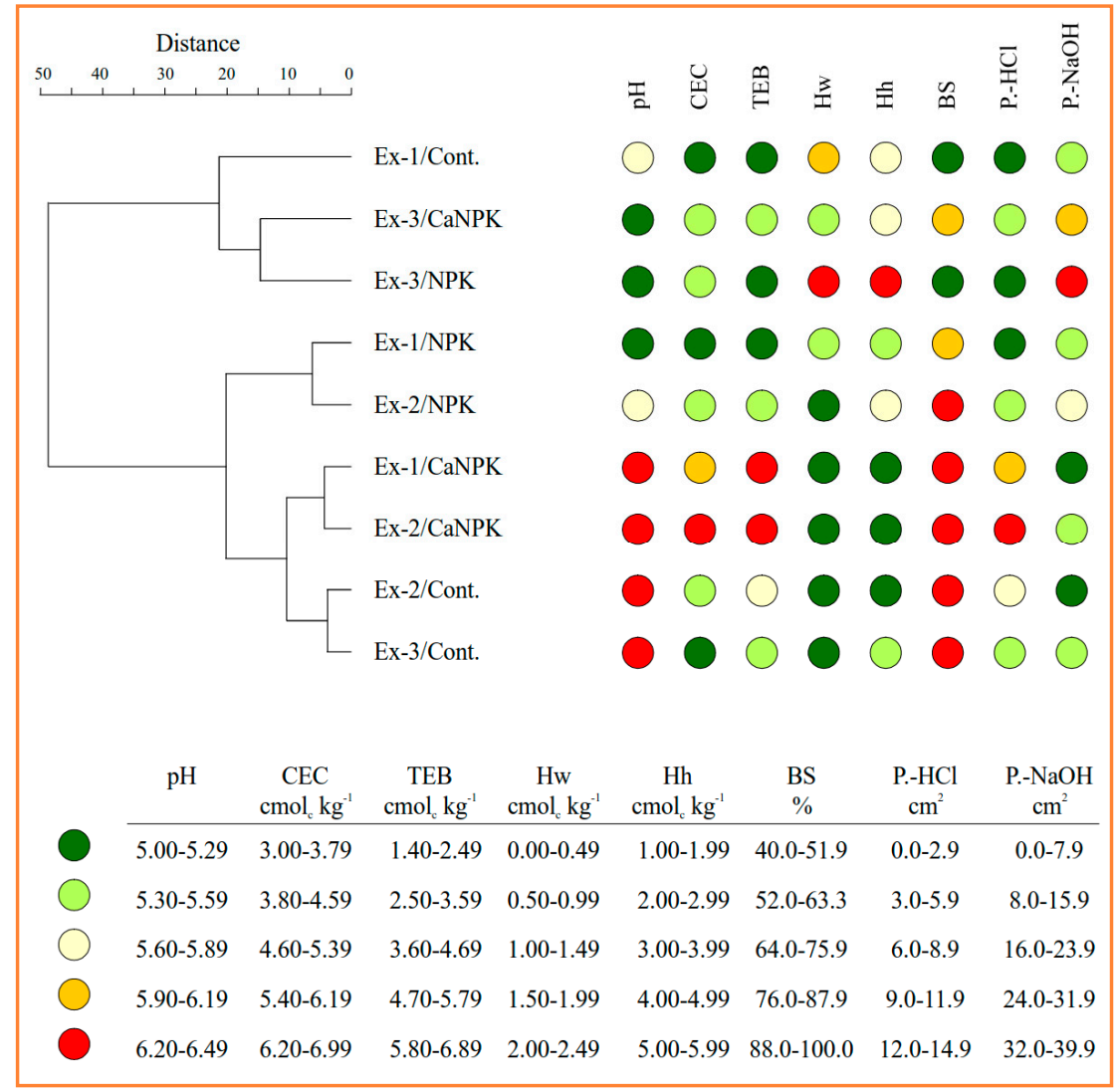

Figure 9 Cluster analysis of the studied soils based on $\mathrm{pHH}_{2} \mathrm{O}, \mathrm{TEB}, H_{w^{\prime}} H_{h^{\prime}} \mathrm{BS}$, $\mathrm{CEC}, \mathrm{PHCl}$ and $\mathrm{PNaOH}$ (Ward method, Euclidean distance)

observed negative effect of nitrogen deposition on buffering capacity of alpine soils. Application of farmyard manure or $\mathrm{CaO}$ considerably increased the ability. Effect of Ca application in experiment 3 was partially neutralized by blueberries. Based on the Ulrich (1981) concept, silicate buffer system is active in most studied soils. This buffer system maintenance soil $\mathrm{pH}$ at level $>5.0$ $\leq 6.3$ and binding of acidic substances by weathering products of primary silicates is responsible mechanism. Higher ability to neutralize alkaline ions than acidic ones was noted in most studied soils. Particularly high $\mathrm{P}-\mathrm{NaOH}$ values were observed at Ex-3/NPK and Ex-3/CaNPK plots (Fig. 8) that were characterized by the highest acidity. The obtained data clearly show strong impact of crops and fertilization on soil buffering capacity, as confirmed by statistically significant differences (Table 2).

Fig. 9 shows combined effects of the studied crops and fertilization practices on soil eco-chemical state indices based on cluster analysis. Two major groups of samples can be distinguished on the graph. The first group covers control plots of experiment 1 and NPK and CaNPK fertilization options in experiment 3. Such layout demonstrates strong impact of blueberries on soil eco-chemical state. The effect is accelerated by application of fertilizers containing ammonium form of nitrogen. Strong acidification, high acidity, low content of exchangeable basis and base saturation, as well as low ability to neutralize acidic ions are typical features of the soils in this group. The second group covers soil affected by manure and/or mineral fertilization under cereals as a crop. These are soils of higher $\mathrm{pH}$ and CEC, lower acidity, and larger ability to neutralize acidic substances.

Table 2 Comparison of chosen soil parameters at control plots (Ex-1/Cont.) vs other options of experiment based on $p$-values, Dunn Test

\begin{tabular}{|l||c|c|c|c|c|c|c|c|}
\hline \multirow{2}{*}{} & \multicolumn{2}{c|}{ Ex-1 } & \multicolumn{3}{c|}{ Ex-2 } & & \multicolumn{2}{c|}{ Ex-3 } \\
\cline { 2 - 9 } & NPK & CaNPK & Cont. & NPK & CaNPK & Cont. & NPK & CaNPK \\
\hline \hline \multirow{2}{*}{ PH-H $\mathbf{2}$} & 0.471 & 0.355 & 0.060 & 0.837 & 0.095 & 0.136 & 0.258 & 0.280 \\
\hline pH-KCI & 0.440 & 0.008 & 0.019 & 0.292 & 0.013 & 0.316 & 0.456 & 0.700 \\
\hline CEC & 0.554 & 0.019 & 0.395 & 0.898 & 0.013 & 0.797 & 0.080 & 0.354 \\
\hline $\boldsymbol{H}_{w}$ & 0.049 & 0.001 & 0.012 & 0.024 & 0.000 & 0.041 & 0.000 & 0.003 \\
\hline $\boldsymbol{H}_{\boldsymbol{h}}$ & 0.016 & 0.518 & 0.276 & 0.009 & 0.260 & 0.039 & 0.000 & 0.003 \\
\hline TEB & 0.341 & 0.001 & 0.018 & 0.064 & 0.001 & 0.051 & 0.670 & 0.090 \\
\hline BS & 0.292 & 0.002 & 0.006 & 0.181 & 0.006 & 0.090 & 0.837 & 0.328 \\
\hline P-HCI & 0.092 & 0.000 & 0.001 & 0.007 & 0.000 & 0.008 & 0.154 & 0.016 \\
\hline P-NaOH & 0.007 & 0.182 & 0.129 & 0.001 & 0.038 & 0.038 & 0.000 & 0.001 \\
\hline
\end{tabular}




\section{Conclusions}

The results of this study clearly demonstrate the importance of crop and fertilization practices for soil eco-chemical state. Both mineral fertilizers and farmyard manure significantly contributed to higher sorptive capacity as compared to control. Lower exchangeable acidity and higher sum of exchangeable basis and base saturation were noted in fertilized soils and cereals as a crop. The studies confirmed strongly acidifying effect of blueberries, in particular in combination with NPK fertilizers, as evidenced by the highest exchangeable acidity, hydrolytic acidity and the lowest base saturation. Liming applied every 4 years partially neutralized the acidifying effect of blueberries. Fertilization and crops also strongly influenced buffering capacity of the studied soils. Extremely low ability to neutralize acidic ions was noted in unfertilized soils, whereas the highest in soils fertilized with $\mathrm{Ca}$ and cereals as a crop. The highest ability to neutralize alkaline ions was typical for fertilized soils under blueberries. In a broader context, this study confirmed huge role of long-term field experiments for understanding processes running in arable soils and their importance to sustain quality and productivity of agricultural soils.

\section{Acknowledgements}

This publication is the result of the project implementation "Scientific support of climate change adaptation in agriculture and mitigation of soil degradation" (ITMS2014+ 313011W580) supported by the Integrated Infrastructure Operational Programme funded by the ERDF.

\section{References}

Bartmiński, P., \& Klimowicz, Z. (2008). Właściwości sorpcyjne czarnych ziem Kotliny Sandomierskiej wytworzonych z różnych skał macierzystych. Roczniki Gleboznawcze, 59(3), 7-16.

Bednarek, R., Dziadowiec, H., Pokojska, U., \& Prusinkiewicz, Z. (2004). Badania ekologiczno-gleboznawcze. PWN.

Błońska, E., \& Januszek, K. (2010). Wpływ składu gatunkowego drzewostanów na aktywność enzymatyczną i właściwości fizykochemiczne gleb leśnych. Roczniki Gleboznawcze, 61(2), 5-14.

Hulugalle, N. R., \& Weaver, T. B. (2005). Short-term variations in chemical properties of Vertisols as affected by amounts, carbon/nitrogen ratio, and nutrient concentration of crop residues. Communications in Soil Science and Plant Analysis, 36, 1449-1464. DOI https://doi.org/10.1081/CSS-200058489

Jaworska, H., Kobierski, M., \& Dąbkowska-Naskręt, H. (2008). Kationowa pojemność wymienna i zawartość kationów wymiennych w glebach płowych o zróżnicowanym uziarnieniu. Roczniki Gleboznawcze, 59(1), 84-89.

Kang, J., Hesterberg, D., \& Osmond, D. L. (2009). Soil organic matter effects on phosphorus sorption: A path analysis. Soil Science Society of America Journal. 73(2), 360-366. DOI https://doi.org/10.2136/sssaj2008.0113
Kowalkowski, A. (2002). Wskaźniki ekochemicznego stanu gleb leśnych zagrożonych przez zakwaszenie. Regionalny Monitoring Środowiska Przyrodniczego, 3, 31-43.

Lieb, A. M., Darrouzet-Nardi, A., \& Bowman, W. D. (2011). Nitrogen deposition decreases acid buffering capacity of alpine soils in the southern Rocky Mountains. Geoderma, 164, 220 224. DOI https://doi.org/10.1016/j.geoderma.2011.06.013

Limon-Ortega, A., \& Martinez-Cruz, E. (2014). Effects of soil $\mathrm{pH}$ on wheat grain yield and quality. Communications in Soil Science and Plant Analysis, 45(5), 581-591. DOI https://doi.org/10.1080/00103624.2013.874018

Malczyk, P., Kobierski, M., Jaworska, H., \& DąbkowskaNaskręt, H. (2008).Zależność między wybranymi właściwościami gleb i pojemnością buforową w glebach uprawnych regionu Pomorza i Kujaw. Roczniki Gleboznawcze, 59(1), 149-154.

Okołowicz, M. (1996). Właściwości sorpcyjne frakcji granulometrycznych wybranych gleb. Roczniki Gleboznawcze, $47(1 / 2), 33-46$.

Orzechowski, M., Smólczyński, S., \& Sowiński, P. (2005). Właściwości sorpcyjne gleb aluwialnych Żuław Wiślanych. Roczniki Gleboznawcze, 56(1/2), 119-127.

PTG. (2009). Klasyfikacja uziarnienia gleb i utworów mineralnych - PTG 2008. Roczniki Gleboznawcze, 60(2), 5-17.

Raczuk, J. (2011). Acidity and buffering properties of soils of the Biała Podlaska Commune. Ochrona Środowiska i Zasobów Naturalnych, 49, 186-192.

Rojas, R., Morillo, J., Usero, J., Delgado-Moreno, L., \& Gan, J. (2013). Enhancing soil sorption capacity of an agricultural soil by addition of three different organic wastes. Science of the Total Environment (pp. 458-460, 614-623). DOI 10.1016/j. scitotenv.2013.04.032

Šimanský, V., Juriga, M., Jonczak, J., Uzarowicz, Ł., \& Stępień, W. (2019). How relationships between soil organic matter parameters and soil structure characteristics are affected by the long-term fertilization of a sandy soil. Geoderma, 342, 75-84. DOI https://doi.org/10.1016/j.geoderma.2019.02.020

Šimanský, V., \& Polláková, N. (2014). Soil organic matter and sorption capacity under different soil management practices in a productive vineyard. Archives of Agronomy and Soil Science, 60(8), 1145-1154.

DOI https://doi.org/10.1080/03650340.2013.865837

Thompson, M., L., Zhang, H., Kazemi, M., \& Sandor, J. A. (1989). Contribution of organic matter to cation exchange capacity and specific surface area of fractionated soil materials. Soil Science, 148, 250-257.

Ulrich, B. (1981). Ökologische Gruppierung von Böden nach ihrem chemischen Bodenzustand. Zeitschrift für Pflanzenernährung und Bodenkunde, 144, 289-305.

Vang, F. L., \& Huang, P. M. (2001). Effects of organic matter on the rate of potassium adsorption by soils. Canadian Journal of Soil Science, 81(3), 325-330. DOI https://doi.org/10.4141/S00-069

Walenczak, K., Licznar, S. E., \& Licznar, M. (2009). The role of organic matter and colloidal clay in forming of buffer properties of soils of the Szczytnicki Park. Soil Science Annual, 60(2), 102-107.

WRB. (2015). World Reference Base for Soil Resources 2014, update 2015. International soil classification system for naming soils and creating legends for soil maps. FAO. 